\title{
EL ESPACIO DE LAS HUMANIDADES
}

La Revista de Literatura Chilena es una revista de humanidades fundada hace más de cuatro décadas. El número 82, que el lector tiene entre manos, incluye once artículos que cumplen con todos los requisitos estipulados por la profesionalización académica en el área. Paradójicamente, cumple también con estas normas el artículo "La tiranía del paper", un trabajo de José Santos en que se aborda críticamente la imposición institucional de un tipo discursivo afín a la carrera académica y a los parámetros que hoy día imperan. ¿Qué implica y cuáles son los desafíos que enfrentan las humanidades en este contexto histórico? ¿Tienen acaso el estatus y el espacio para desempeñar el papel que les corresponde? ¿En qué consiste ese papel? ¿De qué estamos hablando cuando hablamos de humanidades en el ámbito de la educación superior? Las humanidades miran o teorizan -de allí el origen filológico de la voz- lo que suponemos como irreductiblemente humano. Se instalan, por decirlo así, en lo más humano del hombre (y de la mujer), en aquello que los define como tal: su lenguaje, su pensamiento, sus creaciones, su vivencia de la temporalidad, tanto en un plano individual como social, su vocación de trascendencia y de belleza, sus creencias y su proyección futura. En la tradición alemana se habla de "ciencias del espíritu", ciencias (designación tal vez equívoca) que implican una "comprensión" totalizadora más que una mera descripción o inventario, disciplinas más cercanas a la hermenéutica reflexiva y crítica que a la rigidez del dato. Tradicional -y disciplinariamentelas humanidades se configuran en filosofía, historia, lingüística, literatura y lenguas clásicas. No se trata sin embargo de un canon fijo: los estudios de género, la bioética, los estudios cognitivos, los estudios culturales y los estudios regionales también se inscriben en la óptica de las humanidades e interactúan y se nutren con las disciplinas tradicionales.

Pero, ¿qué se espera de estos saberes? ¿Que cumplan solamente un papel de agregación de conocimiento según los parámetros de las ciencias duras, avanzando paso a paso conforme a los micro objetivos de un saber acumulativo y riguroso como el que se supone que debe aportar un buen paper? ¿No existe en esta modalidad el peligro del rigor mortis y de un saber tecnificado? ¿No resulta acaso central en la tradición de las humanidades un pensamiento crítico 
y creativo? ¿No debieran cumplir las humanidades, los estudios literarios incluidos, un rol con respecto a la democracia, al empoderamiento ciudadano y a lo público, como señala la filósofa Martha Nussbaum? ¿Tienen acaso las humanidades el espacio necesario para ello dado las exigencias actuales que operan respecto al rendimiento académico? En relación con esta función primordial ¿no están acaso las humanidades constreñidas por la camisa de fuerza de los rankings, la estandarización, los sistemas de evaluación y las exigencias de los fondos concursables? ¿O estamos acaso perfilando un fantasma que no existe, puesto que esos propios parámetros permiten -como el caballo de Troya- que se los erosione desde su interior, como ocurre por ejemplo con el artículo sobre la "Tiranía del paper" y con la convocatoria que estamos haciendo al abordar este asunto desde una revista hiperindexada? Finalmente ¿será capaz de producir algún efecto un simple picaflor en una jaula de hierro internalizada en las prácticas universitarias del día? ¿No es acaso posible - preguntamos-modificar e incidir en estas prácticas, que a fin de cuentas son históricas y pasajeras?

En fin, aprovechando el artículo de José Santos que se incluye en este número, queremos convocar a un número especial que reflexione (sin ceñirse necesariamente a la tiranía del paper), sobre el papel, el lugar y la significación de las humanidades en el mundo de hoy, sobre todo pensando en nuestra propia realidad universitaria y circunstancia latinoamericana en general. Somos una revista que se inscribe en esa área y que se dedica a los estudios literarios concebidos en el más amplio sentido, y resulta legitimo que en algún momento nos detengamos a pensar en dónde estamos, qué somos y hacia dónde queremos caminar, lo que implica hacerse cargo y tomar una postura frente a la tensión que estamos viviendo: entre la reflexión y creatividad en humanidades y la profesionalización o burocratización y crisis (según algunos) de la investigación y la carrera académica ${ }^{1}$.

Bernardo Subercaseaux

Director

Revista Chilena de Literatura

\footnotetext{
Recogemos inquietudes planteadas entre otros por Martha Nussbaum, Not for profit. Why democracies needs the humanities?, Princeton, 2010; Carlos Ossandón y María Eugenia Góngora, en Documentos internos de trabajo, Facultad de Filosofía y Humanidades, 2010-2012, que abordan fundamentalmente la desvalorización del ensayo y el libro como soporte de la investigación en humanidades.
} 